\title{
Fertility Source and Drought Stress Effects on Plant Growth and Essential Oil Production of Calendula officinalis
}

\author{
Victoria M. Anderson, Douglas D. Archbold, Robert L. Geneve, \\ Dewayne L. Ingram, and Krista L. Jacobsen ${ }^{1}$
}

Department of Horticulture, University of Kentucky, N318 Agriculture Science Building, Lexington, KY 40546

Additional index words. medicinal plants, essential oil, low-input, drought stress, organic agriculture

\begin{abstract}
Organic and low-input production systems are increasingly of interest in medicinal plant production, such as Calendula officinalis, a medicinal plant grown for essential oils. However, in these systems the effects of nutrient availability and water stress may act singularly or in combination to affect plant growth and medicinal compound production. This study investigated the effects of organic and conventional fertility sources and drought stress effects on four calendula cultivars. Soil nitrogen (N) status, plant growth, productivity, and essential oil quality and quantity were measured. The plant growth response to increased $N$ availability varied by cultivar, indicating that some cultivars may be better suited to low-input fertility regimes. Fertility source did not significantly affect essential oil quality or quantity. Drought stress reduced plant growth but increased the quality of essential oil, as indicated by the concentrations of specific constituents, although it did not reduce total oil yield. These results indicate that organic and low-input farming systems may significantly reduce plant growth, but may not necessarily affect essential oil yield or quality. As such, the sustainability of medicinal plant production systems may be improved by reductions in water and conventional fertilizers without significant reductions in medicinal compound production.
\end{abstract}

Calendula (Calendula officinalis L.), or pot marigold, is an herbaceous annual or short-lived perennial (Mohammad and Kashani, 2012) that is widely naturalized and grown for ornamental and medicinal purposes throughout temperate zones. The species has been cultivated since antiquity for its purported general medicinal qualities. Recent work investigating calendula's medicinal properties have reported antimicrobial (Mohammad and Kashani, 2012), antiviral (Kalvatchev et al., 1997), antitumor (Matic et al., 2013), and antiinflammatory (Preethi and Kuttan, 2009; Preethi et al., 2009) effects. Pharmaceutically active compounds in calendula are commonly derived from the "essential oils" distilled from fully open flowers (Gazim et al., 2008; Khalid and Teixeira da Silva, 2010; Okoh et al., 2008). Essential oils, or "volatile oils" are complex mixtures of plant secondary compounds, whose quantity and quality may be affected by cultivar and growing environment (Jha et al., 2011; Khalid and Teixeira da Silva, 2010; Król, 2011; Ozturk et al., 2004).

Calendula varieties grown for ornamental and medicinal purposes both contain essential oils; however, the systems in which they

Received for publication 23 June 2015. Accepted for publication 30 Nov. 2015.

We wish to acknowledge the laboratory and field assistance of Jim Crutchfield, Tami Smith, Alexis Amorese, and Brett Wolff.

${ }^{1}$ Corresponding author. E-mail: krista.jacobsen@ uky.edu. grow may differ considerably. Ornamental cultivars are typically grown on a relatively small scale, often under irrigated and high nutrient input conditions (RezaeiNejad and KhosraviShakib, 2013). In contrast, calendula used for medicinal or oilseed purposes are grown on a relatively large scale, and may be in systems that are water and/or nutrient limited (Forcella et al., 2012).

Understanding how to optimize medicinal plant production under reduced input regimes (e.g., water and fertility) is key to the sustainable and profitable production of calendula and other medicinal plants in a variety of contexts. Calendula grown for essential oil is often produced in semiarid and arid regions where agricultural water is limited (e.g., Khalid and Teixeira da Silva, 2010; Maleki et al., 2014; Metwally et al., 2013). Production of medicinal plants has been suggested as an economic development activity in developing countries (Khalid and Teixeira da Silva, 2010; Srivastava et al., 1996), where access to conventional inputs may be limited (Srivastava et al., 1996). Sustainabilityoriented production systems may be structured with similar constraints. Low external input farming systems seek to minimize purchased off-farm inputs, such as fertilizers and pesticides, and to increase the internal production and cycling of on-farm inputs (Parr et al., 1990). Similarly, organic farming systems often use fertility sources of biological origin (e.g., cover crops, crop residues, composts, and manures) and are based on minimal use of off-farm inputs (USDA NOSB,
1995). In all of these situations, nutrient availability and water limitation present management challenges and may have complex effects on essential oil production in medicinal plants.

Ensuring an adequate $\mathrm{N}$ supply is a key challenge to crop production in these systems (Parr et al., 1990), because the bulk of the $\mathrm{N}$ must be mineralized from the fertility source by microbial decomposition before plant uptake. Consequently, $\mathrm{N}$ availability may be difficult to predict (Gaskell, 2006; Gaskell and Smith, 2007; Hartz et al., 2010), leading to deficiencies that can reduce plant growth (Chand et al., 2011; Nourimand et al., 2012; Siddiqui et al., 2011). Although N stress is generally detrimental to plant growth, the effects on plant secondary compounds are somewhat more complex. Nitrogen deficiency may enhance synthesis of secondary chemicals including antioxidants of medicinal plants (Chand et al., 2011; Nourimand et al., 2012; Siddiqui et al., 2011). However, $\mathrm{N}$ fertilization has also been positively correlated with enhanced secondary compound synthesis and the ability to mitigate oil yield losses caused by drought (Rahmani et al., 2011).

Similarly, drought stress may reduce plant primary productivity, but the effects on secondary compounds are less straightforward. Drought can reduce plant biomass and simply increase the concentrations of secondary metabolites due to reduced fresh biomass in water-restricted plants (de Abreu and Mazzafera, 2005; Liu et al., 2011; Nogues et al., 1998; Selmar and Kleinwaechter, 2013). However, Selmar and Kleinwaechter (2013) opine that this is an oversimplification, and that drought stress may cause a plant to redirect carbon from growth to increased secondary compound production (Selmar, 2008; Selmar and Kleinwaechter, 2013). This may protect the plant from damage induced under stress conditions. For example, the medicinal plants Rosmarinus officinalis L. and Salvia officinalis L. produce more essential oils at higher concentrations when grown under drought stress conditions (Selmar and Kleinwaechter, 2013). The essential oils are effective antioxidants and thus protect the plant from reactive oxygen species that result when water-stressed plants are unable to dissipate surplus absorbed solar energy (Bozin et al., 2007; Selmar and Kleinwaechter, 2013).

The effects of both nutrient supply and water availability on medicinal plant growth and secondary compound production are important to understand singularly. However, in systems using biological sources of fertility, nutrient mineralization is mediated by soil microbial activity, which is highly influenced by moisture and temperature (Drinkwater and Snapp, 2007). As such, plant growth and secondary compound production in medicinal plants grown in these systems is a function of the interaction between the nutrient source and climatic factors. There has been little work examining the interaction of these factors on resource allocation in medicinal plant production, save a few notable exceptions (e.g., Jha et al., 2011; Król, 
2011). Thus, improved understanding of how the interactions between plant growth, development, and secondary compound production are affected by nutrient dynamics and drought stress is important for the sustainable production of medicinal crops, such as calendula.

This work determined the influences of fertility source and water stress on $\mathrm{N}$ availability, plant growth, and essential oil production of four calendula cultivars in a greenhouse setting. Cultivars included herbal and ornamental varieties. Each cultivar was produced using four fertility treatments, including conventional, high-input organic, low external input organic, and no input treatments. Drought stress was induced in each combination of treatments.

\section{Materials and Methods}

Research was conducted at the University of Kentucky Horticulture Research Farm in Lexington, KY $\left(37^{\circ} 58^{\prime} 24^{\prime \prime}\right.$ N, $84^{\circ} 32^{\prime} 5^{\prime \prime}$ W). Soil for the experiment was a Bluegrass Maury silt loam, a fine, mixed, active, mesic Typic Paleudalf. Plant residues were removed from the soil surface, and soil was collected from the $0-15 \mathrm{~cm}$ layer. The soil was collected from a field that was managed according to United States Department of Agriculture (USDA) National Organic Program guidelines for $\approx 5$ years and certified organic for 2 years. The previous soil management regime was summer annual vegetable production with a winter cover crop, with primary tillage occurring once per year, and field cultivation for weed control throughout the growing season. Due to extensive tillage on the site for over 40 years, soil chemical and physical properties were relatively homogenous throughout the plow layer $(0-15 \mathrm{~cm}$, unpublished data).

Soil was passed through a $2-\mathrm{mm}$ sieve, amended with one of three fertilizers, and then packed into slightly tapered square pots (13.31 $\mathrm{cm}$ by $13.31 \mathrm{~cm}$ at the top) $(1230-\mathrm{mL}$ volume) to simulate bulk density of the field soil $\left(1.4 \mathrm{~g} \cdot \mathrm{cm}^{-3}\right)$. Fertilizer treatments included: 1) a "no external input" organic treatment consisting of unamended field soil, 2) a "low external input organic" treatment consisting of locally composted cattle manure approved for use in USDA certified organic production applied at a rate considered an upper economic threshold for compost application in organic field crops (10 tons.ac, or $\left.22 \mathrm{t} \cdot \mathrm{ha}^{-1}\right)$. This rate corresponded to $234 \mathrm{~kg} \cdot \mathrm{ha}^{-1}$ actual $\mathrm{N}(0.7-0.3-0.1 ; 40.6: 1$ $\mathrm{C} / \mathrm{N})$, which is equivalent to a $23 \mathrm{~kg} \cdot \mathrm{ha}^{-1}$ rate per year when calculated to release evenly over a 10-year period (Sanchez and Richard 2009); 3) a "high-input organic" treatment amended with a commercially available organic granular fertilizer derived from pelletized poultry manure (5-2-3), approved for UDSA Certified Organic production (Organic Materials Review Institute, Eugene, OR), applied at a rate of $157 \mathrm{~kg} \cdot \mathrm{ha}^{-1}$ actual $\mathrm{N}$, and 4) a conventional treatment consisting of granular conventional fertilizer (19-8-16), applied at a rate of $157 \mathrm{~kg} \cdot \mathrm{ha}^{-1}$ actual $\mathrm{N}$.
After packing amended soils into pots, four seeds of a single cultivar were planted in each. After germination, plants were thinned to a single plant per pot. The four cultivars selected included three herbal cultivars: Alpha (Alpha), Resina (Resina), an unspecified cultivar (Jelitto), as well as an ornamental cultivar Sunshine Flashback (Flashback). Alpha and Resina are marketed as larger-stature cultivars $(60-75 \mathrm{~cm})$ with high resin content for medicinal or edible flower production. Alpha is earlier maturing $(50-55 \mathrm{~d})$ than Resina (55-60 d). Jelitto is marketed as a shorter-stature cultivar $(40 \mathrm{~cm})$ for medicinal and edible flower production (days to maturity not available). Flashback is marketed as an ornamental cultivar selected for uniformity in flowering, is shorter-stature $(30-45 \mathrm{~cm})$ and later maturity $(55-60 \mathrm{~d})$.

Pots were arranged in a randomized complete block design, with four replicate blocks, each on a separate greenhouse bench. There was one pot per treatment per block for each of the three sampling dates. The pot size and spacing corresponded to a planting density of 60 plants $/ \mathrm{m}^{2}$, to simulate the crop canopy of a field with 600,000 plants/ha, a plant density identified in previous work to maximize calendula essential oil production (Berimavandi et al., 2011). Soil moisture was maintained at a gravimetric water content corresponding to a volumetric water content between $75 \%$ field capacity $(-78 \mathrm{kPa})$ and field capacity $(-33 \mathrm{kPa})$, determined by previous soil moisture release curves for the soil (unpublished data). No water escaped from the containers during water application. Pots were weighed daily during the germination and establishment period, and on alternating days thereafter, to maintain desired water content. After the harvest of the first flower, water availability was reduced on one-half of the plants to induce drought stress by allowing pots to dry to a gravimetric moisture content corresponding to $40 \%$ field capacity $(-431 \mathrm{kPa})$, and maintained at this level for the duration of the experiment by daily weighing and watering. Daily water use was recorded at each weighing and watering event. Throughout the experiment, the greenhouse was maintained at a $28{ }^{\circ} \mathrm{C}$ day $/ 15.5{ }^{\circ} \mathrm{C}$ night temperature regime. The average daily light integral was $10.0 \mathrm{MJ} \cdot \mathrm{m}^{-2}$.

One pot per treatment per block was destructively sampled for measurement of soil mineral $\mathrm{N}$ at 0,30 , and $96 \mathrm{~d}$, as well as stem height, aboveground biomass, leaf area, and stem $\mathrm{NO}_{3}-\mathrm{N}$ at 30 and $96 \mathrm{~d}$. Soil mineral $\mathrm{N}$ was measured by colorimetric analysis from a subsample of soil by extraction in $1 \mathrm{M} \mathrm{KCl}$ (Rice et al., 1984). Samples were allowed to settle and analyzed for $\mathrm{NH}_{4}{ }^{+}-\mathrm{N}$ and $\mathrm{NO}_{3}{ }^{-} \mathrm{N}$ by colorimetric analysis on a microplate reader (Molecular Devices, VERSAmax Sunnyvale, CA), after $\mathrm{NO}_{3}{ }^{-}$ samples had been reduced using a cadmium reduction device (ParaTechs Co., Lexington, KY) (Crutchfield and Grove, 2011). Stem nitrate $\left(\mathrm{NO}_{3}-\mathrm{N}\right)$ was measured with a Laqua Twin Nitrate Meter (Spectrum Technologies, Plainfield, IL). Leaf area was measured using a leaf area meter (LI-COR LI-3100, Lincoln, $\mathrm{NE}$ ). Aboveground biomass was recorded fresh at harvest, then dried in a $60{ }^{\circ} \mathrm{C}$ oven for $24 \mathrm{~h}$ or until a constant mass was achieved, and weighed for dry biomass. On the final sampling date, unopened flower buds were counted. Predawn plant water potential was measured using a pressure chamber instrument (Model 615, PMS Instrument Company, Albany, OR) at the final harvest date ( $96 \mathrm{~d}$ ) from the oldest previously harvested flower stem with a complete callus (indicating the cutting wound had completely healed), or from a fresh harvested flower stem if there had been no flowers harvested up to that point.

Flower heads were harvested throughout the experiment when they were fully open, which was identified as flowers with the third row of florets open (57-95 d after sowing for primary flowers and 61-96 d after sowing for secondary flowers). Flower heads were excised using a razor, and immediately placed in liquid N. Flowers were stored at $-80{ }^{\circ} \mathrm{C}$ until analysis of volatile compounds. The primary and first secondary flowers harvested (first and second flower from each plant) delineated predrought and postdrought stress conditions; drought stress was induced after harvest of the first flower but before the first secondary flowers were collected. Plant maturation was slightly delayed in conventional treatments, and there were insufficient flowers for a complete data set of primary and secondary conventional flower pairs, thus they are excluded from this analysis. Three replicates per treatment were analyzed for secondary compounds.

Flowers were analyzed by head space solid phase microextraction (SPME) (Gazim et al., 2008; Sigal Escalada and Archbold, 2009). Flowers were removed from the freezer, immediately weighed, and placed into a $237-\mathrm{mL}$ bottle with septum cap, along with $4.1 \mu \mathrm{g}$ of 1-octanol (in hexane) as an internal standard. The bottle was sealed and placed in a water bath at $35^{\circ} \mathrm{C}$ and incubated for $15 \mathrm{~min}$ without an SPME fiber. Then, the bottle headspace was collected for $15 \mathrm{~min}$ through a $100-\mathrm{mm}$ poly(dimethylsiloxane) fiber. The SPME fiber was removed and injected into a gas chromatograph (GC) (Model Hewlett Packard 5890 Series II; Agilent Technology, Wilmington, DE) equipped with a DB-5 column $(60 \mathrm{~m} \times$ $0.32 \mathrm{~mm}$ i.d., $1-\mu \mathrm{m}$ film thickness) and a flame ionization detector. Helium carrier gas had a linear velocity of $30 \mathrm{~cm} \cdot \mathrm{s}^{-1}$. A modified splitless injection port was used so that the septum and inlet purges were interrupted during SPME injections. Volatiles were desorbed from the fiber in the GC injection port for $5 \mathrm{~min}$ at $250{ }^{\circ} \mathrm{C}$. Upon opening the purge valve, analytical conditions were as follows: initial oven temperature, $50{ }^{\circ} \mathrm{C}$ held for $2 \mathrm{~min}$ and then increased to $140{ }^{\circ} \mathrm{C}$ at $2{ }^{\circ} \mathrm{C}$ per min, then rising to $210^{\circ} \mathrm{C}$ at a rate of $5^{\circ} \mathrm{C}$ per min with a 2 -min hold. Preliminary analyses indicated that all major volatiles emerged from the column within the 63-min run time. 
Because essential oil production was of interest and several wound volatile compounds were also produced by the methods used, the area units of common wound volatile products, and also 1-octanol, were removed from the total area units of volatile production. The major wound volatile products were tentatively identified as hexanal, trans-2-hexenal, and cis-3-hexenal from retention times of standards. The remaining area units of total volatile production were used to calculate total essential oil production. $\alpha$-Pinene, reported to be a major constituent of calendula essential oil (Kaskoniene et al., 2011), was selected as a proxy for evaluating essential oil quality, the retention time was identified using standard $\alpha$-pinene, and it was also quantified. Total essential oil and $\alpha$-pinene production are reported as ng of 1-octanol per $g$ of flower tissue based on a 1-octanol internal standard.

Data were analyzed by PROC Mixed with SAS version 9.3 (SAS Institute, Cary, NC) using least squares means and pairwise differences to separate means.

\section{Results}

Soil mineral $N$. Soil mineral $\mathrm{N}$ results are presented as total soil mineral $\mathrm{N}\left(\mathrm{NO}_{3}{ }^{-}+\right.$ $\mathrm{NH}_{4}^{+}$) and were largely reflective of soil $\mathrm{NO}_{3}{ }^{-}$content; the quantity of $\mathrm{NH}_{4}{ }^{+}$was negligible $\left(<3.5 \mathrm{~kg} \cdot \mathrm{ha}^{-1}\right)$ at all sampling dates, with the exception of $0 \mathrm{~d}$ in the conventional treatment $\left(19 \mathrm{~kg} \cdot \mathrm{ha}^{-1}\right)$ due to the $\mathrm{NH}_{4}{ }^{+}$present in the conventional fertilizer. Soil mineral $\mathrm{N}$ was significantly affected by type of amendment $(P<0.0001)$, time $(P<0.0001)$, and the interaction between amendment and time $(P<0.0001)$. When averaged over time, the highest level of mineral $\mathrm{N}$ was found in soil amended with conventional fertilizer $\left(90.1 \mathrm{~kg} \cdot \mathrm{ha}^{-1} \pm 3.2\right)$ and the lowest in unamended soil (28.7 $\mathrm{kg} \cdot \mathrm{ha}^{-1} \pm 1.2$ ). Mean soil mineral $\mathrm{N}$ in compost and organic granular fertilizer treatments did not differ significantly $(54.1 \pm 2.0$ and $51.0 \pm 2.4 \mathrm{~kg} \cdot \mathrm{ha}^{-1}$, respectively). Trends in soil mineral $\mathrm{N}$ were similar in all treatments, peaking at $30 \mathrm{~d}$, and declining to levels similar to the unamended soil by $96 \mathrm{~d}$ (data not shown). The organic high-input treatment (poultry litter based) did not differ from the soil mineral $\mathrm{N}$ content in the no input system at $0 \mathrm{~d}$. At $30 \mathrm{~d}$, soil mineral $\mathrm{N}$ content differed significantly between treatments. Soil mineral N levels increased significantly in both organic treatments, with a marked increase $\left(70 \mathrm{~kg} \cdot \mathrm{ha}^{-1}\right)$ in the poultry litter-based (high input organic) amendment. After $96 \mathrm{~d}$ soil mineral $\mathrm{N}$ levels had declined to below $20 \mathrm{~kg} \cdot \mathrm{ha}^{-1}$ in all treatments, although the two high-input sources (conventional and organic) did not differ significantly, and were significantly greater than the compost and no amendment treatment (Fig. 1).

Although soil mineral $\mathrm{N}$ levels were low in all treatments at the end of the experiment, none of the plants showed visible signs of nutrient deficiency such as chlorosis or other

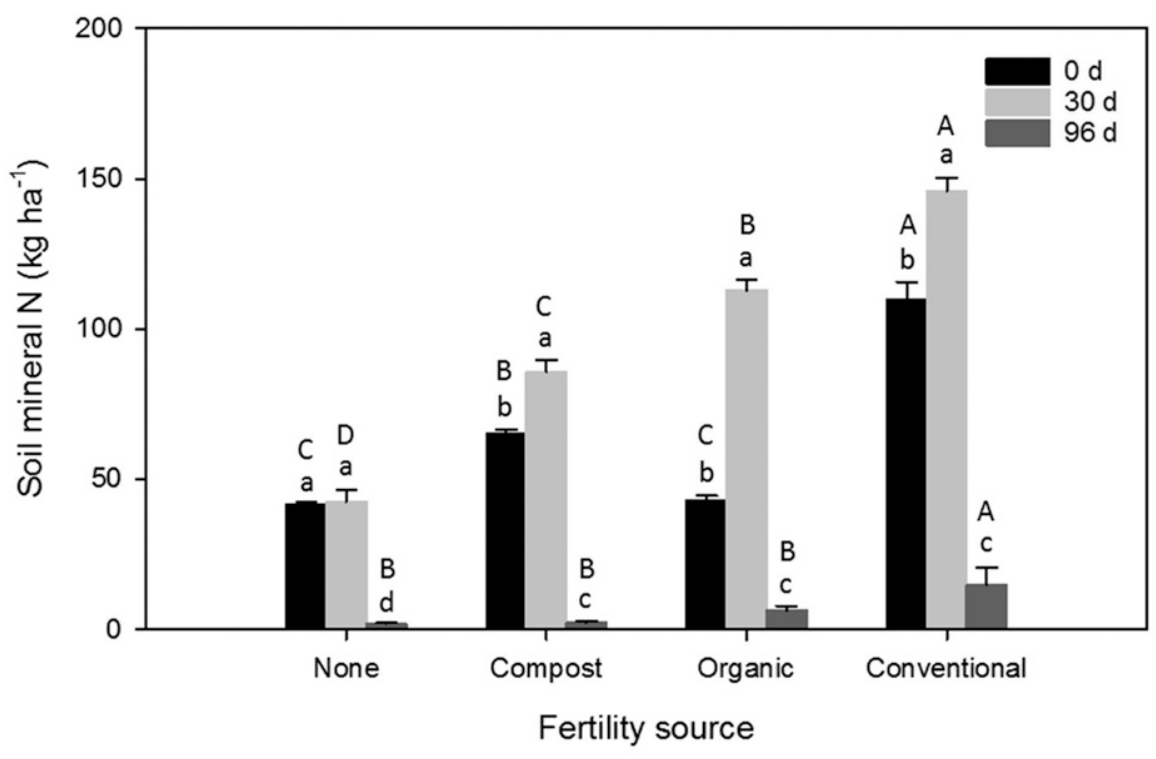

Fig. 1. Mean total soil mineral N (+ $1 \mathrm{SE})$ at each sampling date by amendment. Means with the same lower case letter are not significantly different within each amendment $(P<0.05)$. Means with the same upper case letter are not significantly different within each sampling date $(P<0.05)$.

discoloration of leaf or other plant tissue. Stem nitrate content was between 85 and 150 ppm $\mathrm{NO}_{3}-\mathrm{N}$ in all treatments. Stem sap $\mathrm{NO}_{3}-$ $\mathrm{N}$ was not significantly influenced by amendment or cultivar. Water-stressed plants had insufficient sap to make a determination of stem $\mathrm{NO}_{3}-\mathrm{N}$.

Plant growth and biomass. Calendula biomass was significantly influenced by amendment $(P<0.0001)$, cultivar $(P<$ $0.0001)$, water stress $(P=0.0105)$, and the interaction between cultivar and amendment $(P=0.0087)$. Plants grown in soil without additional fertilizer had the smallest biomass, while biomass in amended treatments did not differ significantly. The two larger stature medicinal varieties had the greatest biomass (Resina and Jelitto), while the smaller medicinal variety and the ornamental (Alpha and Flashback, respectively) did not differ significantly. Plants that were maintained with adequate water had a significantly higher biomass than those maintained under water stress conditions (Table 1). Significant cultivar by amendment interactions indicated that some varieties may respond to increased soil mineral $\mathrm{N}$ levels to a greater extent than other varieties. Two of the medicinal varieties (Jelitto and Resina) had greater biomass in soil amendment treatments corresponding to amendments with increasing soil mineral $\mathrm{N}$ content at 0 and $30 \mathrm{~d}$ (Fig. 2A). However, soil $\mathrm{N}$ levels were not correlated to biomass or leaf area $\left(R^{2} \leq 0.28\right)$. One variety, Flashback, did not demonstrate increased biomass in any amendment treatment.

Leaf area was significantly affected by amendment $(P=0.0068)$, cultivar $(P<$ $0.0001)$, water stress $(P<0.0001)$ (Table 1$)$, and the interaction of amendment and water stress $(P=0.0007)$. Leaf area was least in the unamended soil and did not differ significantly among amended treatments, which was similar to the trends in biomass. Water- stressed plants had, on average, one-half of the leaf area of nonstressed plants. Resina and Jelitto had significantly greater leaf area than Alpha. Flashback did not differ significantly from Alpha or Jelitto. The greatest leaf areas were produced in treatments amended with either organic or conventional fertilizer supplied with adequate water (Fig. 2B).

Date of first flower was significantly affected by amendment $(P=0.0016)$. Compost and unamended treatments both flowered at $70 \mathrm{~d}$, while organic and conventional fertilizer treatments flowered at $76 \mathrm{~d}$ (Table 1). The lack of cultivar differences indicates the effect of fertility source outweighed the effect of cultivar on date to flowering. Drought stress was not induced until first flowers appeared, thus it had no bearing on this variable.

Flower count (total number of flowers per plant) was influenced by cultivar $(P=0.0081)$ and water stress $(P=0.0056)$. Plants from the nonstressed treatments produced significantly more flowers than plants from the unstressed treatment (Table 1).

Flower weight was significantly affected by cultivar $(P<0.0001)$, drought stress $(P=0.0003)$, flower order (primary vs. secondary flower, $P<0.0001$ ) (Table 2), and the interaction between cultivar and flower order $(P<0.0001)$ (data not shown). Average flower weight was greater in the early maturing herbal varieties, Alpha and Jelitto, than the ornamental Flashback and later maturing herbal Resina. Flowers from well-watered plants were significantly heavier than those from drought-stressed plants, and primary flowers were heavier than secondary flowers. Mass of the primary flowers of Alpha and Jelitto were greater than mean flower mass of all cultivars at any harvest order (Table 2). 
Table 1. Main treatment effects on Calendula officinalis growth metrics.

\begin{tabular}{llccccc}
\hline Effect & \multicolumn{1}{c}{ Treatment } & $\begin{array}{c}\text { Biomass } \\
(\mathrm{g} / \mathrm{plant})\end{array}$ & $\begin{array}{c}\text { Leaf area } \\
\left(\mathrm{cm}^{2} / \text { plant }\right)\end{array}$ & $\begin{array}{c}\text { Date of first } \\
\text { flower (DAS) }\end{array}$ & $\begin{array}{c}\text { Flower yield } \\
\text { (flowers/plant) }\end{array}$ & $\begin{array}{c}\text { Bud count } \\
\text { (buds/plant } \\
\text { at } 96 \mathrm{~d})\end{array}$ \\
\hline Amendment & Organic & $4.0 \mathrm{a}^{\mathrm{z}}$ & $513 \mathrm{a}$ & $76.0 \mathrm{a}$ & 2.7 & $1.9 \mathrm{a}$ \\
& Conventional & $4.0 \mathrm{a}$ & $480 \mathrm{a}$ & $76.0 \mathrm{a}$ & 2.8 & $1.5 \mathrm{ab}$ \\
& Compost & $3.5 \mathrm{a}$ & $479 \mathrm{a}$ & $69.8 \mathrm{~b}$ & 3.3 & $1.5 \mathrm{ab}$ \\
Drought & None & $2.6 \mathrm{~b}$ & $399 \mathrm{~b}$ & $70.1 \mathrm{~b}$ & 2.9 & $1.0 \mathrm{~b}$ \\
& Nonstressed & $3.7 \mathrm{a}$ & $613 \mathrm{a}$ & 74.4 & $3.2 \mathrm{a}$ & $2.0 \mathrm{a}$ \\
& Drought-stressed & $3.3 \mathrm{~b}$ & $322 \mathrm{~b}$ & 73.4 & $2.5 \mathrm{~b}$ & $1.0 \mathrm{~b}$ \\
& Resina & $3.70 \mathrm{~b}$ & $545 \mathrm{a}$ & 73.5 & $2.6 \mathrm{ab}$ & 1.8 \\
& Jelitto & $4.23 \mathrm{a}$ & $495 \mathrm{ab}$ & 75.3 & $3.4 \mathrm{a}$ & 1.6 \\
& Flashback & $3.13 \mathrm{c}$ & $432 \mathrm{bc}$ & 72.6 & $3.3 \mathrm{ab}$ & 1.4 \\
& Alpha & $3.11 \mathrm{c}$ & $398 \mathrm{c}$ & 74.1 & $2.3 \mathrm{~b}$ & 1.3 \\
\hline
\end{tabular}

DAS $=$ days after sowing

${ }^{\mathrm{z}}$ Means with the same letter are not significantly different $(P \leq 0.05)$ within each main effect.

\section{$\mathbf{A}$}

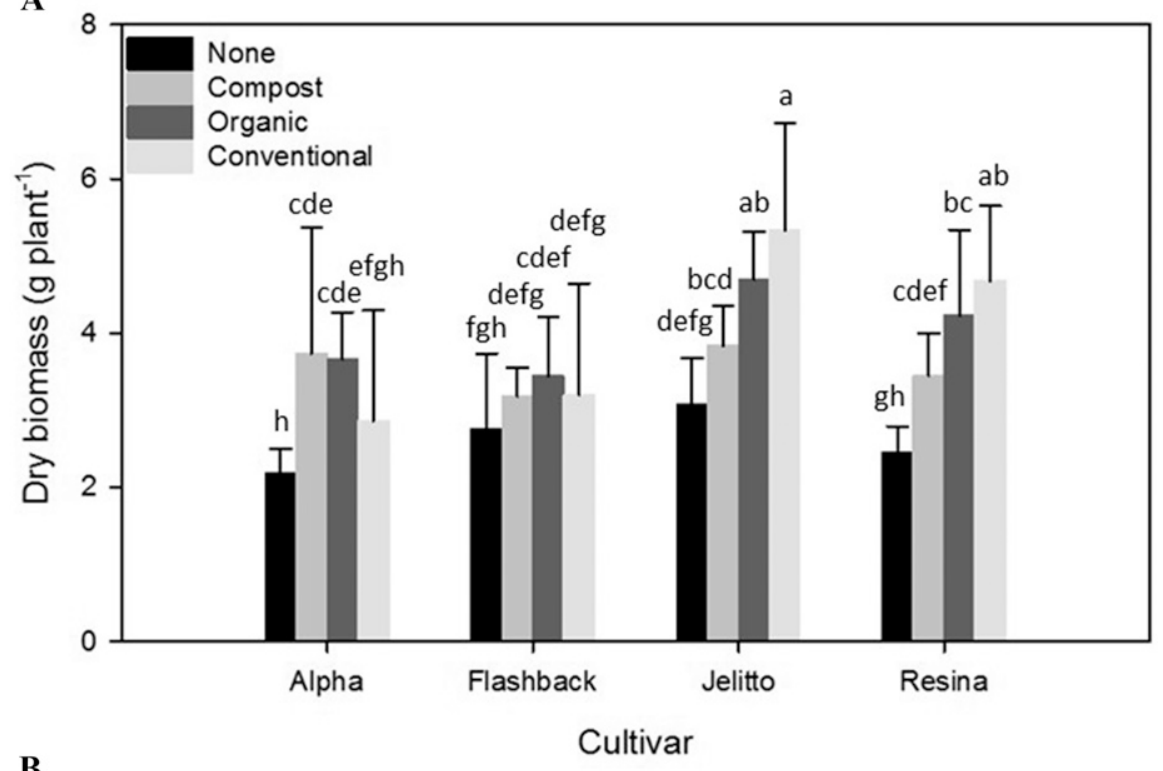

B

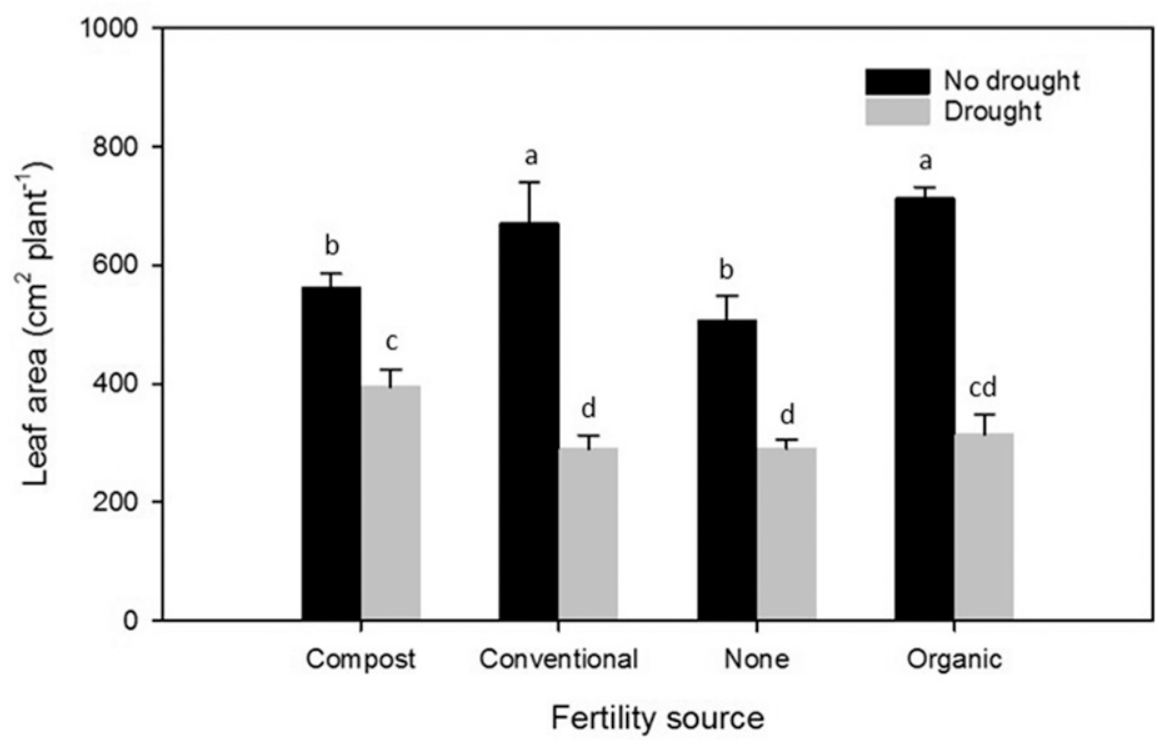

Fig. 2. (A) Effect of fertility source on dry biomass of four cultivars of Calendula officinalis. Values (means $+\mathrm{SE}$ ) with the same letter are not significantly different $(P \leq 0.05)$. (B) Effect of drought stress on leaf area of $C$. officinalis grown in four fertility treatments. Values (means $+\mathrm{sE}$ ) with the same letter are not significantly different $(P \leq 0.05)$.

Bud count reflects the number of unopened flowers on each plant at $96 \mathrm{~d}$, and is indicative of potential flower count. Bud

count was significantly influenced by amendment $(P=0.0324)$ and drought stress $(P<$ 0.0001 ) (Table 1). Bud count in the organic
Table 2. Effect of cultivar and flower order on Calendula officinalis flower weight.

\begin{tabular}{lcc}
\hline Cultivar & Flower order & $\begin{array}{c}\text { Mean flower } \\
\text { wt (g/flower) }\end{array}$ \\
\hline Alpha & Primary & $4.4 \mathrm{a}^{\mathrm{z}}$ \\
Jelitto & Primary & $3.3 \mathrm{~b}$ \\
Flashback & Primary & $1.8 \mathrm{c}$ \\
Resina & Primary & $1.7 \mathrm{c}$ \\
Alpha & Secondary & $1.6 \mathrm{c}$ \\
Jelitto & Secondary & $1.2 \mathrm{c}$ \\
Flashback & Secondary & $1.1 \mathrm{c}$ \\
Resina & Secondary & $1 \mathrm{c}$ \\
\hline${ }^{z}$ Means with the same letter are not significantly
\end{tabular}
different $(P \leq 0.05)$.

treatment was the only treatment significantly greater (nearly double) than the unamended treatment. Nonstressed plants had twice the number of buds as drought-stressed plants (Table 1).

Essential oil quality and quantity. Calendula essential oil consists of several volatile compounds, including those identified as essential oil constituents, wound products, and unidentified compounds contributing to total essential oil production. Volatile compounds were analyzed from the first (primary) and second (secondary) flowers produced, which represent predrought and postdrought flowers, respectively. The concentration of $\alpha$-pinene, a key essential oil in calendula (Kaskoniene et al., 2011), was greatest in Resina and Alpha varieties, although Alpha did not differ significantly from the other two varieties $(P=0.068)$ (Table 3). Drought-stressed flowers had a greater concentration of $\alpha$-pinene than nonstressed flowers $(P<0.0001)$, as did secondary flowers on average as compared with primary flowers $(P<0.0001)$. The main effects of drought stress and flower order were modified by their interaction, with secondary drought-stressed flowers measuring 2.5 times the concentration of primary flowers and nearly double the concentration of secondary nonstressed flowers $(P=$ 0.0004) (Table 3).

Significant effects and interactions on total essential oil are similar to the trends in effects on $\alpha$-pinene. The total essential oil concentration was significantly influenced by cultivar $(P=0.0005)$, drought stress $(P<$ $0.0001)$, flower order $(P<0.0001)$, and the interaction of water stress and flower order $(P<0.0001)$. Resina and Flashback had higher concentrations of total essential oils than Jelitto and Alpha. The significant main effect of water stress was driven by the concentrations in secondary drought-stressed flowers, which had nearly double the concentration of total volatile oils of secondary nonstressed flowers. Secondary flowers from the nonstressed treatment were similar to primary flowers (Table 3).

The quantity of total oil produced per flower varied significantly by variety $(P<$ $0.0001)$. Alpha produced at least $20 \%$ more oil per flower than the other cultivars, followed by Flashback and Resina. Resina did not differ significantly from Flashback or Jelitto (Table 3 ). The effect of total oil per 
flower on variety was modified by the interaction with amendment in which the varieties were grown $(P=0.0004)$. Alpha grown in compost had greater total oil per flower than any other variety by amendment combination. Alpha grown in other amendments did not differ in total oil per flower from Flashback in compost or Jelitto in organic fertilizer. Jelitto grown in organic fertilizer had greater total oil per flower than when grown in other treatments. Resina oil quantity was unaffected by amendment (Fig. 3). Variety by amendment interactions were further modified by the three-way interaction of variety by amendment by water stress $(P=$ 0.0099). Flashback and Resina oil production per flower did not differ significantly with any treatment combination. Jelitto had the greatest oil quantity when grown with organic fertilizer without water stress, but when grown in water-stressed conditions yields did not differ from plants grown without additional fertilizer. Alpha had the greatest total oil per flower of all treatment combinations when grown in compost, both with and without water stress. However, when not water stressed, Alpha oil production did not differ significantly when grown in compost from plants grown without additional fertilizer. When water stressed, however, Alpha total oil production was greatest in the fertilized treatments (Fig. 4).

Primary flowers had greater total oil per flower than secondary flowers $(P<0.0001)$. However, the effect of flower order was modified by water stress $(P=0.0445)$ with primary flowers having greater total oil production than secondary flowers, followed by nonstressed secondary flowers. Secondary drought-stressed flowers had the lowest total oil production per flower (Table 3 ). Neither amendment nor drought were significant main effects, but the interaction was significant $(P=0.0322)$. This was driven by the low total oil produced in the unamended drought stress treatment. Total oil produced in the other amendment by drought stress treatment combinations did not differ significantly (data not shown).

\section{Discussion}

Cultivar selection is one of the primary considerations in constructing plant production systems, and significantly affected leaf area, flower yield, flower weight, and essential oil quantity and quality. The cultivars used in this work were selected for commercial availability in the study region. Interestingly, the ornamental cultivar (Flashback) did not consistently differ significantly from Jelitto or Resina growth and oil yield metrics, and had greater oil production per flower than Jelitto, a medicinal variety. However, the four cultivars represent a small sampling of cultivar diversity. A recent global estimate of calendula varieties estimated over 100 cultivars of calendula currently in cultivation, most of which are grown for ornamental purposes (Richter, 2007). This diversity is significant in generalizing results from this
Table 3. Effects of cultivar, drought stress, and flower order on the quality and quantity of essential oil in Calendula officinalis.

\begin{tabular}{|c|c|c|c|c|c|}
\hline \multirow[b]{2}{*}{ Effect } & \multirow[b]{2}{*}{ Treatment } & \multirow[b]{2}{*}{$\begin{array}{l}\text { Flower wt } \\
\text { (g/flower) }\end{array}$} & \multicolumn{2}{|c|}{$\begin{array}{l}\text { Constituent concn } \\
\text { (ng. } \mathrm{g}^{-1} \text { fresh flower) }\end{array}$} & \multirow{2}{*}{$\begin{array}{c}\text { Total oil } \\
\text { per flower } \\
\text { (ng/fresh flower) }\end{array}$} \\
\hline & & & $\alpha$-Pinene & $\begin{array}{c}\text { Total } \\
\text { volatile oil }\end{array}$ & \\
\hline \multirow[t]{4}{*}{ Cultivar } & Alpha & $3.0 \mathrm{a}^{\mathrm{z}}$ & $3,160 \mathrm{ab}$ & $27,601 \mathrm{~b}$ & $56,741 \mathrm{a}$ \\
\hline & Flashback & $1.4 \mathrm{c}$ & $2,555 \mathrm{~b}$ & $40,227 \mathrm{a}$ & $45,446 \mathrm{~b}$ \\
\hline & Jelitto & $2.3 \mathrm{~b}$ & $2,717 \mathrm{~b}$ & $29,049 \mathrm{~b}$ & $40,607 \mathrm{c}$ \\
\hline & Resina & $1.4 \mathrm{c}$ & 3,979 a & $43,072 \mathrm{a}$ & $44,493 \mathrm{bc}$ \\
\hline \multirow[t]{2}{*}{ Drought stress } & Nonstressed & $2.4 \mathrm{a}$ & $2,238 \mathrm{~b}$ & $26,725 \mathrm{a}$ & 47,802 \\
\hline & Drought-stressed & $1.7 \mathrm{~b}$ & $3,967 \mathrm{a}$ & $43,250 \mathrm{~b}$ & 45,841 \\
\hline \multirow[t]{2}{*}{ Flower order } & Primary & $2.8 \mathrm{a}$ & $2,120 \mathrm{~b}$ & $24,361 \mathrm{a}$ & $50,702 \mathrm{a}$ \\
\hline & Secondary & $1.2 \mathrm{~b}$ & $4,085 \mathrm{a}$ & $45,614 \mathrm{~b}$ & $42,941 \mathrm{~b}$ \\
\hline \multirow{4}{*}{$\begin{array}{l}\text { Flower order } \times \\
\text { drought stress }\end{array}$} & Primary nonstressed & 3.1 & $1,803 \mathrm{c}$ & $22,125 \mathrm{c}$ & $50,151 \mathrm{a}$ \\
\hline & Primary drought-stressed & 2.5 & $2,437 \mathrm{bc}$ & $26,597 \mathrm{bc}$ & $51,254 \mathrm{a}$ \\
\hline & Secondary nonstressed & 1.7 & $2,674 \mathrm{~b}$ & $31,325 \mathrm{~b}$ & $45,454 \mathrm{~b}$ \\
\hline & Secondary drought-stressed & 0.8 & $5,497 \mathrm{a}$ & $59,902 \mathrm{a}$ & $40,428 \mathrm{c}$ \\
\hline
\end{tabular}

${ }^{\mathrm{z}}$ Means with the same letter are not significantly different $(P \leq 0.05)$.

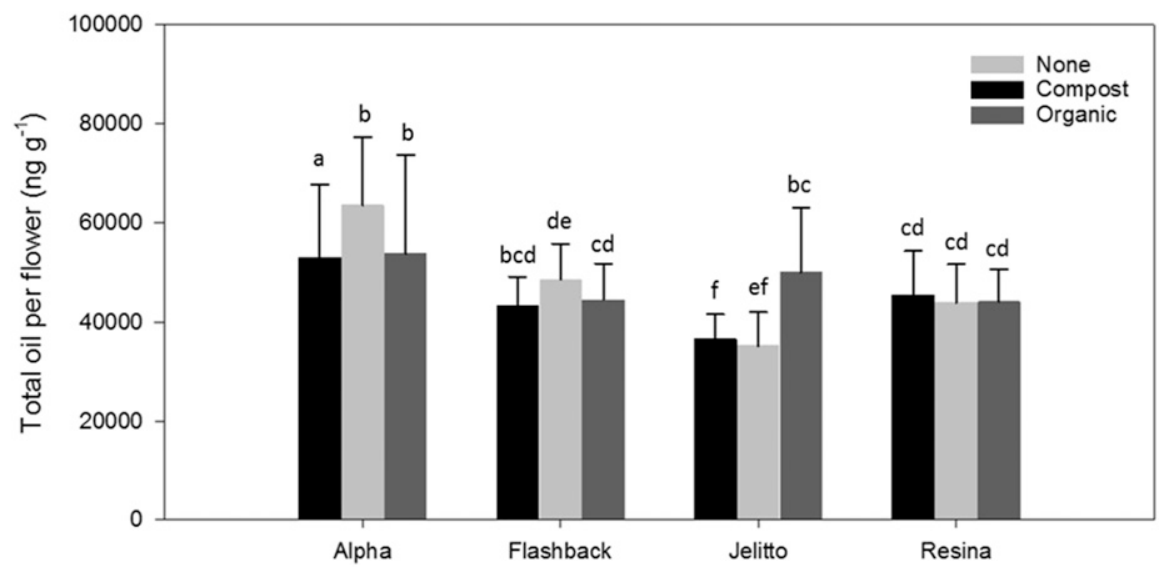

Fig. 3. Effect of fertility source on total essential oil yield of four cultivars of Calendula officinalis. Values $($ means $+\mathrm{SE})$ with the same letter are not significantly different $(P \leq 0.05)$.

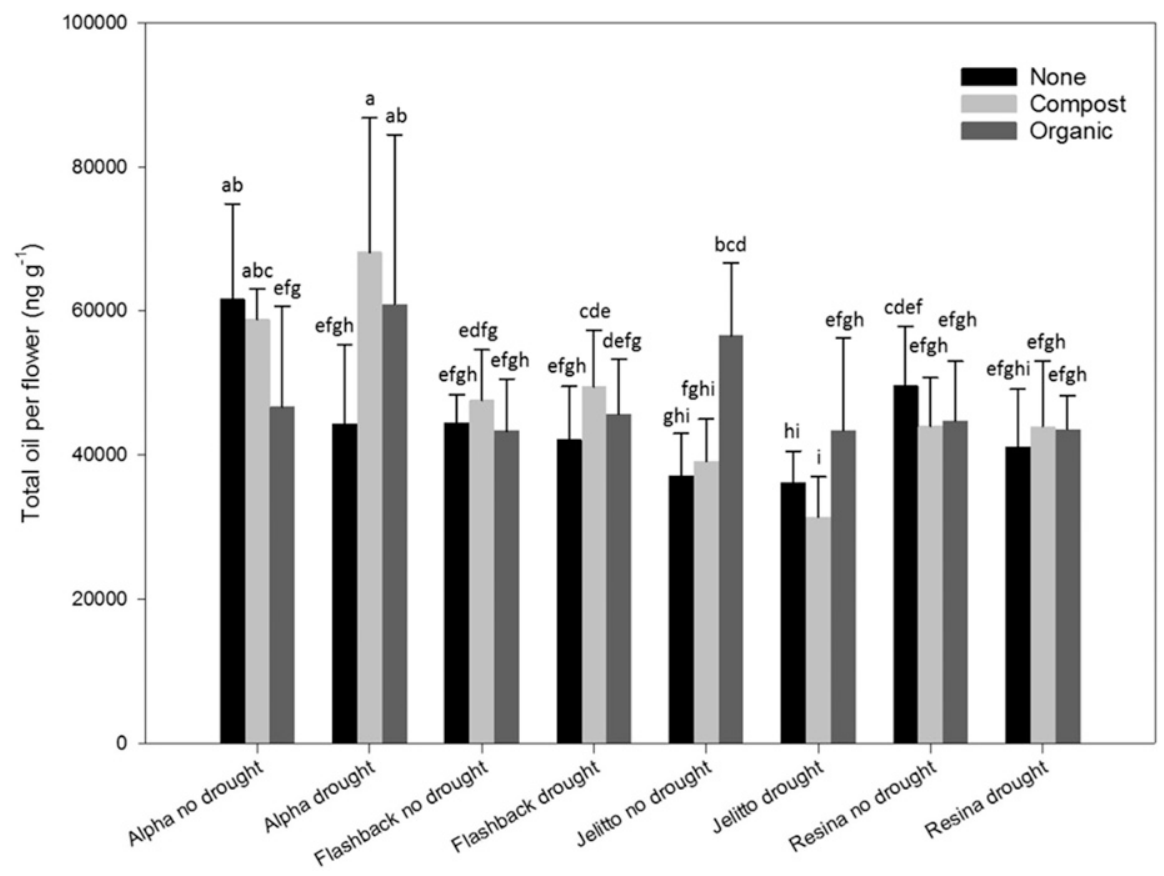

Fig. 4. Effect of fertility source and drought stress on total oil produced per flower of four Calendula officinalis cultivars. Values (means $+\mathrm{SE})$ with the same letter are not significantly different $(P \leq 0.05)$. 
work, which indicates that a cultivar is not only influenced by these main effects, but also responds differentially to management of inputs such as fertility source and water regime. Previous work has indicated that variation among cultivars often obscures the influence of production systems on the profile of secondary compounds (Brandt and Molgaard, 2001).

Fertility source. The fertility treatments were selected to represent a range of inputs with varying degrees of nutrient availability. Fertility treatments significantly affected soil mineral $\mathrm{N}$ content and metrics associated with plant primary productivity, but did not affect volatile oil quantity or quality.

The soil mineral $\mathrm{N}$ dynamics in this work were consistent with prior reports on nutrient availability from biological amendments. Although soils fertilized with biological amendments often exhibit lower initial mineral $\mathrm{N}$ than conventional systems, biological amendments may have total $\mathrm{N}$ quantities equivalent to conventional fertilizers that will be available upon decomposition and subsequent mineralization (Drinkwater et al., 1995). Previous work examining $\mathrm{N}$ mineralization using biological amendments in organic farming systems demonstrated that recalcitrant amendments, such as compost, may mineralize only $10 \%$ of total $\mathrm{N}$ in 6 months following incorporation (Hartz et al., 2000 ). In contrast, $60 \%$ to $80 \%$ of total $\mathrm{N}$ was mineralized from poultry litter-based amendments within 2 months of application (Hartz and Johnstone, 2006). It is unclear from the methods used in this study to what extent total $\mathrm{N}$ from the amendments was exhausted vs. being released in close synchrony with plant $\mathrm{N}$ uptake (Drinkwater and Snapp, 2007). Nitrogen losses from leaching were assumed to be negligible, as the watering procedure did not allow any leachate to escape. However, we did not account for potential gaseous losses in this work.

In general, there were few significant differences in plant growth metrics between the amended treatments. Plants did not appear to be visibly nutrient stressed in any treatment, suggesting that all amended treatments had sufficient nutrients available to produce plants with equivalent final growth metrics. Further, plants in all amended treatments reached physiological maturity without significant differences in flower count or volatile oil quality affected by the main effect of amendment. These results are consistent with other work in low-input calendula production systems. For example, Król (2011) observed calendula flower yield increased with additional $\mathrm{N}$ fertilizer up to $80 \mathrm{~kg}$ actual $\mathrm{N} / \mathrm{ha}$, after which there was no further increase.

The compost and no amendment treatments flowered an average of $6 \mathrm{~d}$ earlier than the treatments with commercial conventional and organic fertilizers. Other low-input fertility work found that control plants (without supplemental N) flowered in the shortest length of time while plants receiving the most $\mathrm{N}$ took the longest time to flower (Król 2011).
The significant interactions of amendment with cultivar and with water stress indicate that amendment choice may have more complex effects on calendula productivity when considered in concert with other management factors. Cultivar by amendment effects suggest that cultivars respond differentially to soil mineral $\mathrm{N}$ availability in both primary and secondary compound productivity, and thus that some cultivars may be better suited to lower input systems. For example, Flashback biomass and total volatile oil production per plant did not differ between amendment treatments, indicating that greater inputs have little potential to improve growth and essential oil production. Alpha, a less vigorous cultivar, showed equivalent biomass when grown in compost or either of the commercial fertilizers, and greater volatile oil production when grown in compost compared with organic fertilizer. The biomass of the two vigorous medicinal varieties (Jelitto and Resina) responded to the variability in soil mineral $\mathrm{N}$ content in the first $30 \mathrm{~d}$ of the experiment generated by the fertility treatments to a greater extent than the other cultivars. However, Resina volatile oil quantity did not differ between fertility treatments, whereas Jelitto had significantly greater total oil production when grown in commercial organic fertilizer. Thus, plant vigor and other physiological characteristics of the cultivar may interact with nutrient availability or other aspects of the fertilizer to modify the growth and oil production per flower of a given cultivar, with some cultivars exhibiting greater plasticity in this response than others.

Drought stress. The effect of water regimes, and specifically periods of drought stress, is salient in both understanding how to optimize medicinal calendula production in dry land systems, and the deliberate use of water restriction to increase essential oil quality and quantity in calendula flowers (Khalid and Teixeira da Silva, 2010; Rahmani et al., 2011; Taherkhani et al., 2011). The drought-stressed treatment was designed to replicate a moisture-rich planting season followed by limited water availability later in the growing season, as can be common in the study region (midsouthern United States). The degree of drought stress in the treatment may be characterized as moderate to severe, as it resulted in some growth reduction (Yordanov et al., 2000), as opposed to a less severe stress, which would not reduce plant biomass (Gray et al., 2003). In addition to biomass reduction due to water stress, the stressed plants produced fewer and smaller secondary flowers than nonstressed plants. There were twice as many buds on nonstressed plants at the end of the experiment, an indication that future flower yield would be reduced in water-stressed plants. The interaction of drought stress and amendment demonstrates that the greatest leaf areas were produced in soils amended with either organic or conventional fertilizer and supplied with adequate water, indicating that leaf area is correlated with higher $\mathrm{N}$ availability and adequate water supply (Fig. 2B).
On average, flowers on water-stressed plants had the highest concentrations of total essential oils (Table 2). Secondary flowers also had a greater concentration of total essential oils than primary flowers on nonstressed plants. The concentration of compounds produced by water-stressed secondary flowers was $47 \%$ greater than nonstressed secondary flowers and was almost $60 \%$ greater than that of water-stressed primary flowers. Water stress triggers significant increases in secondary compounds in other medicinal plants (de Abreu and Mazzafera, 2005; Liu et al., 2011; Nogues et al., 1998; Selmar, 2008; Selmar and Kleinwaechter, 2013).

Gray et al. (2003) suggested that the increase in total essential oil concentration as a result of water stress may not fully compensate for the decline in biomass caused by the stress when considering total oil produced per flower. However, our results demonstrate that although drought stress affected flower biomass, it did not significantly affect total oil produced per flower when averaged across both primary and secondary flowers. However, this effect is modified by flower order, because primary flowers produced greater total oil quantity than secondary flowers, and further, secondary water-stressed flowers exhibited lower total oil produced than the other treatments. This pattern indicates declining oil quantity per flower as drought progressed. Conversely, had the drought stress treatment been less severe and the experiment carried out longer, total oil may not have been compromised by drought stress and higher concentrations of total oils maintained under lower water use conditions. It is also of note that this experiment was conducted in the autumn season, as daylight levels began to decrease in the Northern Hemisphere, and plant growth slowed toward the end of the experiment. Increased length of study and additional study cycles would have further informed the trends from this greenhouse experiment. Future work to elucidate the optimum degree and timing of drought stress would prove useful in improved understanding of how intentional water restriction may increase oil yields while allowing for reduced water inputs in various calendula production systems in the field environment.

\section{Conclusions}

This work demonstrates that under varying moisture and input scenarios, choice of plant cultivar, fertility source, and management of soil water status affects plant primary productivity and essential oil production. This work indicates that fertility source and drought stress may significantly affect soil mineral $\mathrm{N}$ content and metrics associated with plant primary productivity, but may not necessarily affect volatile oil quantity or quality in calendula. Cultivars responded differentially to soil mineral $\mathrm{N}$ availability in both primary and secondary compound productivity, and therefore some cultivars may be better suited to lower fertility inputs than others. Water stress increased the concentration of total essential 
oils in calendula flowers, and although it did affect flower biomass, on average the reductions in biomass did not significantly affect total oil produced per flower. However, interactions between drought stress and flower order may indicate the total oil production may be reduced in drought stresses plants over time. Future systems-level work exploring the interactions of water stress and nutrient dynamics on a greater variety of cultivars may elucidate broader trends in low-input production systems on plant growth and essential oil production for optimizing yields with inputs in low-input and dryland production systems.

\section{Literature Cited}

de Abreu, I.N. and P. Mazzafera. 2005. Effect of water and temperature stress on the content of active constituents of Hypericum brasiliense Choisy. Plant Physiol. Biochem. 43:241-248.

Berimavandi, A.R., D. Hashemabadi, M.V.F Ghaziani, and B. Kaviani. 2011. Effects of plant density and sowing date on the growth, flowering and quantity of essential oil of Calendula officinalis L. J. Med. Plants Res. 5:5110-5115.

Bozin, B., N. Mimica-Dukic, I. Samojlik, and E. Jovin. 2007. Antimicrobial and antioxidant properties of rosemary and sage (Rosmarinus officinalis L. and Salvia officinalis L., Lamiaceae) essential oils. J. Agr. Food Chem. 55:7879-7885.

Brandt, K. and J.P. Molgaard. 2001. Organic agriculture: Does it enhance or reduce the nutritional value of plant foods? J. Sci. Food Agr. 81:924-931.

Chand, S., A. Pandey, M. Anwar, and D.D. Patra. 2011. Influence of integrated supply of vermicompost, biofertilizer and inorganic fertilizer on productivity and quality of rose scented geranium (Pelargonium species). Indian J. of Nat. Prod. Resour. 2:375-382.

Crutchfield, J.D. and J.H. Grove. 2011. A new cadmium reduction device for the microplate determination of nitrate in water, soil, plant tissue, and physiological fluids. J. AOAC Intl. 94:1896-1905.

Drinkwater, L.E., D.K. Letourneau, F. Workneh, A.H.C. Vanbruggen, and C. Shennan. 1995. Fundamental differences between conventional and organic tomato agroecosystems in California. Ecol. Appl. 5:1098-1112.

Drinkwater, L.E. and S.S. Snapp. 2007. Nutrients in agroecosystems: Rethinking the management paradigm. Adv. Agron. 92:163-186.

Forcella, F., S.K. Papiernik, and R.W. Gesch. 2012. Postemergence herbicides for calendula. Weed Technol. 26:566-569.

Gaskell, M. 2006. Organic nitrogen sources for vegetable crops. HortScience 41:957.

Gaskell, M. and R. Smith. 2007. Nitrogen sources for organic vegetable crops. HortTechnology 17:431-441.

Gazim, Z.C., C.M. Rezende, S.R. Fraga, B.P. Dias Filho, C.V. Nakamura, and D.A.G. Cortez. 2008. Analysis of the essential oils from $\mathrm{Ca}$ lendula officinalis growing in Brazil using three different extraction procedures. Revista Brasileira de Ciências Farmacêuticas 44:391-395.

Gray, D.E., S.G. Pallardy, H.E. Garrett, and G.E. Rottinghaus. 2003. Effect of acute drought stress and time of harvest on phytochemistry and dry weight of St. John's wort leaves and flowers. Planta Med. 69:1024-1030.
Hartz, T.K. and P.R. Johnstone. 2006. Nitrogen availability from high-nitrogen-containing organic fertilizers. HortTechnology 16:39-42.

Hartz, T.K., J.P. Mitchell, and C. Giannini. 2000. Nitrogen and carbon mineralization dynamics of manures and composts. HortScience 35:209-212.

Hartz, T.K., R. Smith, and M. Gaskell. 2010. Nitrogen availability from liquid organic fertilizers. HortTechnology 20:169-172.

Jha, P., M. Ram, M.A. Khan, U. Kiran, Y.M. Mahmooduzzafar, and M.Z. Abdin. 2011. Impact of organic manure and chemical fertilizers on artemisinin content and yield in Artemisia annua L. Ind. Crops Prod. 33:296-301.

Kalvatchev, Z., R. Walder, and D. Garzaro. 1997. Anti-HIV activity of extracts from Calendula officinalis flowers. Biomed. Pharmacother. 51:176-180.

Kaskoniene, V., P. Kaskonas, M. Jalinskaite, and A. Maruska. 2011. Chemical composition and chemometric analysis of variation in essential oils of Calendula officinalis L. during vegetation stages. Chromatographia 73:S163-S169.

Khalid, K.A. and J.A. Teixeira da Silva. 2010. Yield, essential oil and pigment content of Calendula officinalis L. flower heads cultivated under salt stress conditions. Sci. Hort. 126:297305.

Król, B. 2011. Yield and the chemical composition of flower heads of pot marigold (Calendula officinalis L. cv. Orange King) depending on nitrogen fertilization. Acta Sci. Pol. Hortorum Cultus 10:235-243.

Liu, H.Y., X.D. Wang, D.H. Wang, Z.R. Zou, and Z.S. Liang. 2011. Effect of drought stress on growth and accumulation of active constituents in Salvia miltiorrhiza Bunge. Ind. Crops Prod. 33:84-88.

Maleki, A., A. Feizolahi, R. Naseri, K. Rezaei, and M.M. Heydari. 2014. Effects of different fertilizer sources on vegetative characteristics of pot marigold plant (Calendula officinalis L.). Intl. J. Biosci. 5:242-249.

Matic, I.Z., Z. Juranic, K. Savikin, G. Zdunic, N. Nadvinski, and D. Godevac. 2013. Chamomile and marigold tea: Chemical characterization and evaluation of anticancer activity. Phytother. Res. 27:852-858.

Metwally, S.A., K.A. Khalid, and B.H. AbouLeila. 2013. Effect of water regime on growth, flower yield, essential oil and proline contents of Calendula officinalis. Nus. Biosci. 5:65-69.

Mohammad, S.M. and H.H. Kashani. 2012. Pot marigold (Calendula officinalis) medicinal usage and cultivation. Sci. Res. Essays 7:14681472 .

Nogues, S., D.J. Allen, J.I.L. Morison, and N.R. Baker. 1998. Ultraviolet-B radiation effects on water relations, leaf development, and photosynthesis in droughted pea plants. Plant Physiol. 117:173-181.

Nourimand, M., S. Mohsenzadeh, and J.A.T. da Silva. 2012. Physiological responses of fennel seedling to four environmental stresses. Iran J. Sci. Technol. Trans. (A1):37-46.

Okoh, O.O., A.P. Sadimenko, O.T. Asekun, and A. J. Afolayan. 2008. The effects of drying on the chemical components of essential oils of $\mathrm{Ca}$ lendula officinalis L. Afr. J. Biotechnol. 7:1500-1502.

Ozturk, A., A. Unlukara, A. Ipek, and B. Gurbuz. 2004. Effects of salt stress and water deficit on plant growth and essential oil content of lemon balm (Melissa officinalis L.). Pak. J. Bot. 36:787-792.

Parr, J.F., R.I. Papendick, I.G. Youngberg, and R.E. Meyer. 1990. Sustainable agriculture in the United States, p. 50-67. In: C. Edwards, R. Lal, P. Madden, R.H. Miller, and G. House (eds.). Sustainable agriculture systems. Soil and Water Conservation Society, Ankeny.

Preethi, K.C., G. Kuttan, and R. Kuttan. 2009. Anti-inflammatory activity of flower extract of Calendula officinalis Linn. and its possible mechanism of action. Indian J. Exp. Biol. 47:113-120.

Preethi, K.C. and R. Kuttan. 2009. Wound healing activity of flower extract of Calendula officinalis. J. Basic Clin. Phys. Pharm. 20:73-79.

Rahmani, N., J. Daneshian, H.A. Farahani, and T. Taherkhani. 2011. Evaluation of nitrogenous fertilizer influence on oil variations of calendula (Calendula officinalis L.) under drought stress conditions. J. Med. Plants Res. 5:696701.

RezaeiNejad, A. and A. KhosraviShakib. 2013. Ornamental value of Calendula officinalis "Yellow Gitana" as a result of nitrogen fertilizer and plant density. Inter. Jour. Agric. Crop Sci. 5:362-365.

Rice, C.W., M.S. Smith, and J.M. Crutchfield. 1984. Inorganic-N analysis of soil extracts by automated and distillation procedures. Commun. Soil Sci. Plant Anal. 15:663-672.

Richter, C. 2007. Commercial calendula cultivation. Richters herbs. 22 Feb. 2015. <www. richters.com/show.cgi?page=MagazineRack/ Articles/CommercialCalendulaCultivation.html $>$.

Sanchez, E.S. and T.L. Richard. 2009. Using organic nutrient sources. Pennsylvania State University Extension Publication UJ256. 2 Mar. 2015. <http://pubs.cas.psu.edu/freepubs/ $\mathrm{pdfs} / \mathrm{uj} 256 . \mathrm{pdf}>$.

Selmar, D. 2008. Potential of salt and drought stress to increase pharmaceutical significant secondary compounds in plants. Landbauforsch Volkenrode 58:139-144.

Selmar, D. and M. Kleinwaechter. 2013. Influencing the product quality by deliberately applying drought stress during the cultivation of medicinal plants. Ind. Crops Prod. 42:558-566.

Siddiqui, Y., T.M. Islama, Y. Naidu, and S. Meon. 2011. The conjunctive use of compost tea and inorganic fertiliser on the growth, yield and terpenoid content of Centella asiatica (L.) urban. Sci. Hort. 130:289-295.

Sigal Escalada, V. and D.D. Archbold. 2009. Preharvest aminoethoxyvinylglycine plus postharvest heat treatments influence apple fruit ripening after cold storage. HortScience 44:1637-1640.

Srivastava, J., J. Lambert, and N. Vietmeyer. 1996. Medicinal plants: An expanding role in development. World Bank Technical Paper, World Bank, Washington, DC

Taherkhani, T., N. Rahmani, A.M. Aghdam, and P. Zandi. 2011. Assessment of nitrogen levels on flower yield of calendula grown under different water deficit stresses using drough tolerant indices. J. Am. Sci. 7:591-598.

USDA NOSB. 1995. As compiled by Gold MV Alternative Farming Systems Information Center. 1 Mar. 2015. <http://www.nal.usda.gov/ afsic/pubs/ofp/ofp.shtml>.

Yordanov, I., V. Velikova, and T. Tsonev. 2000. Plant responses to drought, acclimation, and stress tolerance. Photosynthesis 38:171-186. 